\title{
Pitch Canker Disease of Pines
}

\author{
T. R. Gordon
}

Department of Plant Pathology, University of California, Davis 95616.

Accepted for publication 6 January 2006.

\begin{abstract}
Gordon, T. R. 2006. Pitch canker disease of pines. Phytopathology 96:657-659.

Pitch canker, caused by Fusarium circinatum, is a disease affecting pines in many locations throughout the world. The pathosystem was originally described in the southeastern (SE) United States and was identified in California in 1986. Limited vegetative compatibility group (VCG) diversity in the California population of $F$. circinatum, relative to the SE United States, suggests the former is a recently established and clonally propagating population. Although the much greater VCG diversity found in the SE United States is suggestive of out-crossing, molecu-

lar markers indicate that many vegetatively incompatible isolates are clonally related. This implies that VCG diversity may derive, at least in part, from somatic mutations rather than sexual reproduction. Pitch canker is damaging to many pine species and one at particular risk is Monterey pine (Pinus radiata), which is widely grown in plantations and is highly susceptible to pitch canker. However, some Monterey pines are resistant to pitch canker and some severely diseased trees have been observed to recover. The absence of new infections on these trees reflects the operation of systemic induced resistance, apparently in response to repeated infection by the pitch canker pathogen.
\end{abstract}

When a new disease is identified or a known disease is found in a new area, two questions immediately arise: where did the pathogen come from and how much damage will it cause? Any attempt to answer these questions requires information that can only be gained by careful study of the new pathosystem. In that respect, other generic questions may serve the same purpose, which is to provide the impetus to initiate a program of research. Research on a new disease presents opportunities to enrich our understanding of host-parasite interactions, both in revealing details unique to the system under study and in suggesting generalities that may be more broadly applicable.

Questions concerning the origin of the pathogen and the extent to which it might damage potential host species were among those posed when pitch canker, caused by Fusarium circinatum (teleomorph $=$ Gibberella circinata $)$, was identified in California in 1986 by McCain et al. (14). At that time, pitch canker was found to be responsible for extensive mortality of planted Monterey pines (Pinus radiata) along freeway rights-of-way, in state parks, and other landscapes. The two alternative explanations considered for the occurrence of pitch canker in California were that (i) the pathogen was recently introduced to the state and (ii) the pathogen was of long residence in California and only became severe enough to receive notice because a prolonged period of drought predisposed susceptible hosts.

Prior to its discovery in California, pitch canker was known principally as a pathogen of pines in the southeastern (SE) United States, where it was first described by Hepting and Roth in 1946 (12). The pitch canker pathogen can infect wounds caused by insect feeding, weather-related damage, or silvicultural practices. Girdling lesions resulting from branch infections lead to the typical symptoms of canopy dieback, which can be extensive. In the 1970s, pitch canker was the cause of widespread mortality in

Corresponding author: T. R. Gordon; E-mail address: trgordon@ucdavis.edu

DOI: 10.1094/PHYTO-96-0657

(c) 2006 The American Phytopathological Society plantations of slash pine ( $P$. elliottii) in Florida, but since that time, the disease has been largely a chronic problem affecting pines in the SE United States (5).

One of the hallmarks of recently established populations is limited diversity, especially so with fungi that propagate clonally. With this in mind, diversity in the California population of $F$. circinatum was assessed by various means, including vegetative compatibility (3). For comparison, a similar assessment was made of the $F$. circinatum population in Florida, where the pathogen was known to be well established (this collection was made possible through the generous assistance of George Blakeslee at the University of Florida). The results showed a clear difference between the two populations, with 209 California isolates corresponding to five vegetative compatibility groups (VCGs) $(\mathrm{S} / \mathrm{N}=$ 0.02 ) and 117 isolates from Florida being comprised of 45 VCGs $(\mathrm{S} / \mathrm{N}=0.39)$. These findings were consistent with a recent introduction of F. circinatum to California.

Limited diversity in California implied the population of $F$. circinatum was clonally propagating, whereas the much higher level of diversity in Florida implied a history of out-crossing. Subsequent investigations supported the perception that $F$. circinatum was predominantly asexual in California. For example, an assessment of eight polymorphic loci showed that all California isolates associated with the same VCG shared the same multilocus haplotype (23) as would be expected for a population in which clonal propagation predominates. In fact, some isolates that were not vegetatively compatible were also associated with the same multilocus haplotype. A similar pattern was evident in the Florida population, with as many as six VCGs having identical alleles at eight polymorphic loci (23). This result suggested that VCG diversity might derive, at least in part, from somatic mechanisms rather than from out-crossing.

To test the hypothesis that new VCGs arise spontaneously due to mutations affecting het loci, an experimental system was developed to detect such changes. Genetically marked strains were co-cultured and indications of novel compatibility reactions were verified by recovering the modified strain, confirming its deriva- 
tion from the original strain and demonstrating its altered compatibility by pairings with testers. The results showed that, in some cases, isolate pairs that were initially incompatible became compatible due to a change in one of the two isolates (17). In most cases, the altered strain became compatible with a previously incompatible strain and simultaneously lost compatibility with the strain from which it was derived. The frequency of such changes was on the order of $10^{-6}$, which would be high enough to explain the natural occurrence of multiple clonally related VCGs. Thus, VCG diversity in a population may increase over time without the involvement of sexual reproduction.

Although VCG diversity supported the notion that the California population of $F$. circinatum was recently established, it did not reveal any affinity with the Florida population with which it was compared; no compatibility between Florida and California isolates was detected (3). However, molecular markers revealed that two multilocus haplotypes were shared between the two populations. This implicated Florida, or at least some part of the SE United States, as the proximate source of the California infestation. If so, it is quite possible that the pitch canker pathogen was transported from the SE United States to California on seed, where it subsequently became established in seedling nurseries (8). Movement of infested seed also seems likely to explain the introduction of F. circinatum to South Africa (2), where the disease has become a serious problem for nursery production of $P$. patula seedlings (21). In this case, the source of infested seed is presumed to be Mexico (2).

Although pitch canker was recognized in Mexico relatively recently (10), it is possible that the disease is of long residence there. In fact, several lines of evidence suggest the pitch canker pathosystem may have evolved in this part of the world. First, Mexico is the new world center of diversity of the pine genus, being home to over $40 \%$ of described species (16) and pitch canker is known to occur in native forests, where it is reported to cause relatively little damage. Thus, the pathogen appears to behave more like a co-evolved resident than an invasive exotic. In addition, although based on limited sampling, the population of F. circinatum in Mexico appears to be quite diverse $(2,23)$, as would be expected for a pathogen's ancestral home.

An origin in Mexico (or Central America) for the pitch canker pathogen may also be inferred from a recently characterized relationship between $F$. circinatum and $F$. subglutinans, corresponding to the teleomorphic forms G. circinata and G. subglutinans, respectively (4). Isolates of $F$. subglutinans recovered from teosinte (Zea mays sp. mexicana) in southern Mexico and Honduras proved to be interfertile with $F$. circinatum. Overall, fertility between the two species was limited, suggesting they were distinct but closely related enough to hybridize. A close relationship between $F$. circinatum and $F$. subglutinans is also supported by phylogenetic evidence $(15,18)$. The association of $F$. subglutinans with an endemic host species (teosinte) in Mexico may indicate it has a long history in this part of the world. By extension, the closely related $F$. circinatum may trace its origins to this same region.

During the past 20 years, pitch canker has been identified in many new locations worldwide, including South Africa (21) and Chile (25). In both countries, the disease is a problem in seedling nurseries, but the aerial phase of pitch canker, characterized by extensive dieback in the canopy, has not been observed. It is perhaps significant that pines are not native to these countries and most pine-associated insects have not become established there. The absence of insects that are known to be important as wounding agents and vectors of pitch canker (8) may reduce the likelihood of infections on aboveground parts of susceptible trees. However, weather-related injuries and wounds associated with silvicultural practices can also serve as infection courts, and such wounds can be expected to occur wherever pines are grown. Therefore, the absence of canopy dieback may also reflect limita- tions imposed by inoculum availability. That is, if infections can occur only by the chance coincidence of a suitable wound and deposition of airborne spores, inoculum levels may as yet not be sufficient for this to have occurred.

Although pitch canker is now widely distributed, it has yet to become established in many important pine growing countries, such as Australia and New Zealand. Furthermore, there is considerable room for expansion of current infestations. For example, in California, pitch canker is found only in proximity to the coast, where it has caused considerable damage to Monterey pine and to a lesser extent bishop pine ( $P$. muricata) and knobcone pine (P. attenuata), but extensive forested areas within the state and elsewhere in the western United States remain unaffected. Consequently, it is of interest to know the reasons for the present distribution of the disease. Does it reflect a limitation on the pathogen or is it an artifact of the original site(s) of introduction and establishment?

In general, where a pathogen is present, its ability to cause disease will be determined by the availability of a susceptible host in a conducive environment. For pitch canker, the critical environmental components appear to be (i) activity of biotic or abiotic wounding agents and (ii) sufficient moisture during periods when temperature is within a permissive range. Both factors are likely to be important under some circumstances and their relative contributions may be difficult to separate. For example, pitch canker in California is conspicuously more severe near the coast than farther inland (24) and this seems likely to be due, at least in part, to a higher frequency and duration of fog in proximity to the ocean. However, spittlebugs, which provide infection courts by feeding on succulent pine shoots (20) are more common close to the coast and this may also contribute to the observed gradient in disease severity.

The other critical factor in disease development is host susceptibility. Pitch canker is documented to affect at least 51 species of pine and also Douglas-fir (6) but these species vary widely in susceptibility (13). At one extreme, Monterey pine (9) and Mexican weeping pine ( $P$. patula) (22) are among those known to sustain significant damage from pitch canker. At the other end of the spectrum, Japanese black pine ( $P$. thunbergii), Canary Island pine (P. canariensis), and Italian stone pine ( $P$. pinea) are relatively resistant to pitch canker and no mortality caused by this disease has been reported (7). Among pines native to California, most appear to be relatively susceptible to pitch canker (8).

Even for species regarded as susceptible, the degree to which individuals support development of pitch canker can vary widely (9). Thus, the frequency of resistant individuals in a population will influence the extent of damage caused by pitch canker. In Monterey pine, disease-free trees can be found in most stands where pitch canker is otherwise well-established. Although some represent escapes, inoculation tests confirm that many trees are inherently resistant to pitch canker (19). In native forests, differential survival of trees according to their susceptibility implies that selection will enrich the population for resistant individuals over time. However, the magnitude of this effect may be limited by what appears to be rather low heritability of disease resistance (T. R. Gordon, unpublished data).

In addition to intraspecific differences in susceptibility, the level of resistance in an individual may change over time. This was first demonstrated experimentally in Monterey pines by showing that trees with prior exposure to the pitch canker pathogen sustained significantly shorter lesions than genetically identical trees that had never been inoculated (1). The effect was evident throughout the tree and was thus indicative of systemic induced resistance (SIR). That this was not merely an artifact of experimental conditions became apparent when disease remission was confirmed in observation plots. Specifically, trees that were known to have been severely diseased in 1996 were found to be free of symptoms in 1999 (8). 
The lack of symptoms on previously diseased trees reflected the loss of infected tips, which either broke off and/or were obscured by overgrowth of subtending branches. Apparently the pathogen was contained to the extent that axial growth toward the main stem of the tree was restricted. That no new infections occurred was suggestive of SIR, as was observed to occur under experimental conditions (1). To confirm this, trees manifesting disease remission were inoculated in order to directly assess their susceptibility to pitch canker.

Eighty-two trees in seven observation plots were inoculated: three branches on each tree. Where possible, a young Monterey pine, with no evidence of current or old infections was inoculated as a positive control. When branches were rated approximately 20 weeks later, the results showed that nearly all trees manifesting disease remission sustained mean lesion lengths of less than $2.0 \mathrm{~cm}$ (T. R. Gordon, unpublished data), which is consistent with at least moderate resistance to pitch canker (9); control trees sustained substantially longer lesions. This result supports the hypothesis that trees initially susceptible to pitch canker became more resistant over time.

As an independent test of this hypothesis, we compared trees in areas that differed in residence time of pitch canker. Twenty trees in each of 16 plots were inoculated on three branches per tree. Eight plots were in "old" areas, where pitch canker was known to have been present for over 10 years, and the other eight were in "new" areas, where the disease was a relatively recent arrival. Monterey pines located in old areas sustained significantly shorter lesions than trees in new areas (T. R. Gordon, unpublished data), consistent with elevated resistance in trees exposed to the pitch canker pathogen over a longer period of time.

In summary, studies conducted under controlled conditions and both observational and experimental studies in the field show that Monterey pines exposed to the pitch canker pathogen become more resistant over time. This contributes to a small but growing body of literature documenting the occurrence of SIR in woody perennial plants (11). From an evolutionary perspective, SIR may be of importance in providing trees with a means for responding rapidly to new parasites. This may help offset an inherent disadvantage faced by long-lived organisms, with generation times measured in decades, in meeting challenges posed by pests and pathogens with generation times that are orders of magnitude shorter. Thus, induced resistance may serve to sustain populations while the slower process of genetic adaptation leads to the more stable interactions that are typically associated with co-evolved symbionts.

\section{LITERATURE CITED}

1. Bonello, P., Gordon, T. R., and Storer, A. J. 2001. Systemic induced resistance in Monterey pine. For. Pathol. 31:1-8.

2. Britz, H., Coutinho, T. A., Gordon, T. R., and Wingfield, M. J. 2001. Characterization of the pitch canker fungus, Fusarium circinatum, from Mexico. S. Afr. J. Bot. 67:609-614.

3. Correll, J. C., Gordon, T. R., and McCain, A. H. 1992. Genetic diversity in California and Florida populations of the pitch canker fungus, Fusarium subglutinans f. sp. pini. Phytopathology 82:415-420.

4. Desjardins, A. E., Plattner, R. D., and Gordon, T. R. 2000. Gibberella fujikouri mating population A and Fusarium subglutinans from teosinte species and maize from Mexico and Central America. Mycol. Res. 104:865-872.

5. Dwinell, L. D., Barrows-Broaddus, J. B., and Kuhlman, E. G. 1985. Pitch canker: A disease complex of southern pines. Plant Dis. 69:270-276.

6. Gordon, T. R., Kirkpatrick, S. C., Aegerter, B. J., Wood, D. L., and Storer, A. J. 2006. Susceptibility of Douglas-fir (Pseudotsuga menziesii) to pitch canker, caused by Gibberella circinata (anamorph $=$ Fusarium circinatum). Plant Pathol. 55:231-237.

7. Gordon, T. R., Storer, A. J., Okamoto, D., and Wood, D. L. 1998. Susceptibility of five landscape pines to pitch canker, caused by Fusarium subglutinans $\mathrm{f}$. sp. pini. HortScience 33:868-871.

8. Gordon, T. R., Storer A. J., and Wood, D. L. 2001. The pitch canker epidemic in California. Plant Dis. 85:1128-1139.

9. Gordon, T. R., Wikler, K. R., Clark, S. L., Okamoto, D., Storer, A. J., and Bonello, P. 1998. Resistance to pitch canker disease, caused by Fusarium subglutinans $\mathrm{f}$. sp. pini, in Monterey pine (Pinus radiata). Plant Pathol. 47:706-711.

10. Guerra-Santos, J. J. 1999. Pitch canker in Monterey pine in Mexico. Pages 58-61 in: Current and Potential Impacts of Pitch Canker in Radiata Pine. Proc. IMPACT Monterey Workshop, Monterey, CA. M. Devey, C. Matheson, and T. Gordon, eds. CSIRO, Australia.

11. Hammerschmidt, R. 2003. Defense responses in the orchard and the forest. Physiol. Mol. Plant Pathol. 63:235-236.

12. Hepting, G. H., and Roth, E. R. 1946. Pitch canker, a new disease of some southern pines. J. For. 44:742-744.

13. Hodge, G. R., and Dvorak, W. S. 2000. Differential responses of Central American and Mexican pine species and Pinus radiata to the pitch canker fungus. New For. 19:241-258.

14. McCain, A. H., Koehler, C. S., and Tjosvold, S. A. 1987. Pitch canker threatens California pines. Calif. Agric. 41:22-23.

15. O’Donnell, K., Cigelnik, E., and Nirenberg, H. I. 1998. Molecular systematics and phylogeography of the Gibberella fujikuroi species complex. Mycologia 90:465-493.

16. Perry, J. P., Graham, A., and Richardson, D. M. 1998. Pine ecology and biogeography-An introduction. Pages 137-149 in: Ecology and Biogeography of Pinus. D. M. Richardson, ed. Cambridge University Press, Cambridge, UK.

17. Petersen, J. C., and Gordon, T. R. 2005. Spontaneous changes in vegetative compatibility in the ascomycete Gibberella circinata. Phytopathology 95:583.

18. Steenkamp, E. T., Coutinho, T. A., Desjardins, A. E., Wingfield, B. D., Marasas, W. F. O., and Wingfield, M. J. 2001. Gibberella fujikuroi mating population E is associated maize and teosinte. Mol. Plant Pathol. 2:215221.

19. Storer, A. J., Bonello, P., Gordon, T. R., and Wood, D. L. 1999. Evidence of resistance to the pitch canker pathogen (Fusarium circinatum) in native stands of Monterey pine (Pinus radiata). For. Sci. 45:500-505.

20. Storer, A. J., Wood, D. L., Wikler, K. R., and Gordon, T. R. 1998. Association between a native spittlebug (Homoptera: Cercopidae) on Monterey pine and an introduced tree pathogen which causes pitch canker disease. Can. Entomol. 130:783-792.

21. Viljoen, A., and Wingfield, M. J. 1994. First report of Fusarium subglutinans f. sp. pini on pine seedlings in South Africa. Plant Dis. 78:309-312.

22. Viljoen, A., Wingfield, M. J., Kemp, G. H. J., and Marasas, W. F. O. 1995. Susceptibility of pines in South Africa to the pitch canker fungus, Fusarium subglutinans f. sp. pini. Plant Pathol. 44:877-882.

23. Wikler, K., and Gordon, T. R. 2000. An initial assessment of genetic relationships among populations of Fusarium circinatum in different parts of the world. Can. J. Bot. 78:709-717.

24. Wikler, K., Storer, A. J., Newman, W., Gordon, T. R., and Wood, D. L. 2003. The dynamics of an introduced pathogen in a native Monterey pine (Pinus radiata) forest. For. Ecol. Manage. 179:209-221.

25. Wingfield, M. J., Jacobs, A., Coutinho, T. A., Ahumada, R., and Wingfield, B. D. 2002. First report of the pitch canker fungus, Fusarium circinatum, on pines in Chile. Plant Pathol. 51:397. 